\title{
Impact of The Ukrainian Conflict on The Political and Economic Situation in Europe
}

\author{
Mirosław Przygoda \\ University of Warsaw, Faculty of Management, Szturmowa 3, Warsaw, Poland, \\ miroslawprzygoda@wp.pl
}

\begin{abstract}
On 17 March 2014, only one day after the local referendum won by an overwhelming number of votes, the highest authorities of the Autonomous Republic of Crimea approved the decision of the independence of the peninsula including separate City of Sevastopol located within its territory. Subsequently, they requested Moscow to annex the new structure to the Russian Federation. On the same day, the Crimea Republic was recognized as sovereign and independent country by the authorities at Kremlin. Already on 21 March, Crimea together with Sevastopol became a new administrative entity of the largest country in the world. At the beginning of April 2014, two territories bordering with Russia located in the east of Ukraine declared independence. The rebellious areas that assumed the names of the Donetsk People's Republic and Lugansk People's Republic, rejected Kiev's authority and, on 24 May 2014, signed the agreement on the creation of the Federal State of Novorossiya. The situation in the east of Ukraine began to resemble dominoes falling one after the other, slipping out of control of the state authorities. Military counteraction of the government in Kiev, aiming at prevents the disintegration of the country, encountered organized resistance of the separatist forces. International public opinion sided with Ukraine, which aspired to associate with the European Union. To reduce the support for the rebel forces provided by Russia, the latter has been hit with severe economic sanctions. The Russian Federation announced that it will respond by using similar measures against the countries of the West. In the meantime, the conflict in the east of Ukraine has gone into the phase of a permanent battle of two forces on the regional level. Nature and duration of this confrontation indicates that the armed struggle is entering a stage reminiscent of the war that has been ongoing for several years between the Palestinian National Authority and Israel. Just as in the Middle East, this situation may result in the following: the growing tension in this part of the globe and the danger of the conflict spreading into other areas. However, the Ukrainian problem in addition poses the threat of the deterioration of the economic situation in Russia and economic stagnation in the United Europe. In this situation, the following tasks might be of interest: analysis of factors that affect the intransigent attitude of the parties involved in the aforementioned events, possible outcomes of the conflict and forecast of the developments in the upcoming future.
\end{abstract}

Keywords : Conflict, Impact, Russia, Ukraine, Sanctions

\section{Introduction}

The current conflict in Ukraine results from the events of the recent past. Everything started in 1988 with a series of progressive political and economic changes in the Soviet Union, a country that disintegrated in the late 1991. The Soviet Union was replaced by a state organisation which returned to its original name: Russia. As a result of changes in its boundaries, the new international entity has lost almost $24 \%$ of its former territory and more than a half of its population. Despite the losses, the march towards social changes continued along with the emerging free market. Russia opened for ideas and solutions from the West. As a consequence of this trend, in the early 90s the Russian Federation sought accession to NATO. And this was not the first attempt anyway. As early as in March 1954, the authorities of the former USSR sought to end the confrontation with the Western world and expressed the intention to

International Journal of Operations Management, vol. 1, issue 4, pp. 7-15, July 2021 
join NATO. In response, the command of the Alliance presented five conditions to be met by the Soviet Union in order to be admitted to the organisation. They were as follows (Tikhomirov W., 2005):

- consent for a peaceful reunification of Germany,

- making Austria a fully independent country,

- $\quad$ signing of the general disarmament treaty,

- restitution of occupied territories in the Far East to Japan,

- recognition of the fundamental principles of the Charter of the United Nations.

The naivety of the Soviet, and then Russian, authorities observed in the 50s and 90s seems stunning from today's perspective. Both in the mid-twentieth century, and in its last decade, talks concerning Moscow's accession to NATO ended in failure. An attempt of Russia to strengthen the relations with the EU did not succeed either. Executive boards of the European integration group deemed the greatest country in the world not suitable to be a member of the organisation as it failed to comply with the "Copenhagen criteria". As it was established, a member of the Union may only be (Highland MW, 2007, p.125):

"A free, independent, sovereign and democratic European state which adheres to international law and which has a developed market economy capable of competing on a single, common internal market."

Apart from weak economy and insufficiently developed democratic mechanisms, the path to the European Union was barred to the Russian Federation due to allegations of strong promotion of Eurasianism, of no anti-corruption measures and accusations of violating human rights and national minorities.

Politicians of the Union closing "the door to Europe" to Russia and the United States attempting to marginalise the importance of Moscow in the world led the authorities in the Kremlin to seek, in dramatic circumstances, new allies and unprecedented solutions. These aspirations reflected in a proposal to create a Eurasian Union, a political and economic association of Russia, Kazakhstan, Belarus, Kyrgyzstan and Tajikistan. A much more ambitious project was the creation of a group bringing together the so-called "BRICS", including Brazil, Russia, India, China and South Africa. The objectives of the participants of this organisation have been defined as follows:

- to create a new monetary system,

- to increase the role of developing countries in global monetary institutions,

- to reform the United Nations.

In both of the above organisations, the Russian Federation wants to play an absolutely decisive, or even the leading role. In order to secure a privileged position, Moscow's needs to keep the status of superpower and the hitherto owned sphere of influence. A warranty and a key allowing to achieve this goal is to keep Ukraine in its influence area at any price. It might be said that it is a country extremely wealthy in all kinds of natural resources, unique surface goods and a significant human potential. Ukraine is a big country, the third largest state on the continent (following Russia and France). An institutional or public entity that wins influence in Ukraine, will be able to build on this basis its geopolitical power. Without the access to the resources of this country, Russia will not retain its hegemonic position in the entire region. The European Union and its leader, Germany, are never to attain the growth potential of the United States, China, Brazil, India and other most dynamically developing countries of the world.

\section{Further Crisis}

As a result of the revolution started in November 2013 in Maidan, Kiev, Ukraine redefined its orientation from proRussian to pro-European. However, not all residents of the country have accepted the new direction of the policy. Southern and eastern Ukrainian territories, inhabited to a great extent by Russian-speaking population, were strongly in favour of staying in the zone of Russian influence and of keeping the order of things unchanged. This situation might be 
seen as triggered by the direct interference of the Russian Federation in the Ukrainian affairs. The dramatis personae of this process were Russian secret services, the army of this country, or the so-called "volunteers" and a large-scale propaganda employing all the media available.

As early as on 17 March 2014, only one day after the successful local referendum, the highest authorities of the Autonomous Republic of Crimea approved the decision of the independence of this region in the south of Ukraine. The declaration on Crimea independence also included an important army base and a separate City of Sevastopol located within its territory. Subsequently, the authorities of the peninsula requested Moscow to annex the new structure to the Russian Federation. In dozens of hours, the Crimea Republic was recognised by the authorities at Kremlin as a sovereign and independent country. The decision of the parliament dated 21 March made Crimea a new administrative entity and a part of the Russian Federation. And at the beginning of April 2014, two territories bordering with Russia located in the east of Ukraine declared independence. The rebellious areas that assumed the names of the Donetsk People's Republic and Lugansk People's Republic, rejected Kiev's authority and, on 24 May 2014, signed the agreement on the creation of the Federal State of Novorossiya. The situation in the east of Ukraine began to slip out of control of the state authorities. The government in Kiev recurred to military counteraction in order to prevent the disintegration of the country, which encountered organised resistance of the separatist forces. Some time later, the rebel troops were supported by well-trained formations of the regular Russian army equipped with modern weapons. In such circumstances, the scales of victory soon tipped in favour of pro-Russian groups. Ukrainian troops suffered a military defeat which involved thousands of wounded and dead soldiers. Thousands of civilians were affected as well.

\section{Impact of the Conflict on Ukraine}

The phrasing "severe defeat of Ukraine" is not exaggerated. A ceasefire agreement achieved by the participants of the contact group: Ukraine-Russia-OSCE in September 2014 in Minsk, Belarus, is a real defeat of the Kiev government. In the documents signed, Ukraine expressed consent for what it has hitherto definitely refused, namely (Skwieciński P., 2014, p. 80):

- to recognise the separatists as equal partners in the talks held,

- to commit to actual demilitarisation of its eastern regions,

- to agree to grant an unspecified autonomous status for the region of Donbass,

- to allow for a far-reaching political and economic interference of Russia in the affairs of the rebellious districts of Donetsk and Lugansk,

- $\quad$ to suspend economic integration with the EU by the end of 2015.

The conflict in the eastern borderland exposed the previously concealed weakness of Ukraine. It turned out that it is a country struggling with many serious problems, of which the major and at the same time the most visible ones are the following:

- total energy dependence on Russia,

- $\quad$ profound collapse of public finances,

- $\quad$ obsolescence of the army equipment,

- corrupted and insufficient administrative system,

- lack of a coherent domestic and foreign policy,

- increasing poverty of a large part of society,

- lack of compliance with legal provisions in many areas, 
- movements and parties officially operating in the political life that are recognised by Western Europe for their views as obscurantist or illegal.

It would seem that at present the future of Ukraine has not been decided yet. But in fact it has. The answer on its immediate future is to be given as soon as in the coming months. However, all the prognoses regarding it look bleak. One might fear that the current government and state structures will not survive the coming winter period. Cut off gas supplies from Russia may trigger a breakdown of the exhausted and weak Ukrainian economy at any moment now. Increasing problems on the labour market, rampant inflation and the still smouldering armed conflict will lead to the society assuming a radical stance. No expected assistance from NATO, the European Union and passivity of organisations which had been founded for the purpose of international support, such as the World Bank and the European Bank for Reconstruction and Development will result in bitterness, disappointment, dissatisfaction and, most probably, in changing the existing beliefs of the masses formed by the poorest citizens.

The idea of the Ukrainian authorities to close land, air and sea borders with Russia from September 2014 should be considered as an act of final desperation. The intention to stop the large neighbour from meddling in the internal affairs of the state means in fact breaking all contacts with Russia. One shall not forget that Moscow still remains the largest trading partner of Kiev. In 2013, approximately $24 \%$ of the Ukrainian exports went to Russia. At the time, import from Russia amounted to over $30 \%$. In addition, the potential secession of the region of Donbass means a reduction by about $20 \%$ of the Ukrainian GDP hitherto supplied to the state treasury by this region. In fact, the loss is even higher if one takes into account the irretrievable loss of the Crimea, a popular holiday resort with a tourist infrastructure providing considerable revenue and with a military base in Sevastopol bringing Kiev millions of roubles a year for leasing to the Russian army and fleet the land it used (Bohun T., 2014, pp. 88 - 91).

At the moment, the percentage of the public debt in relation to GDP is only $38 \%$. However, this indicator does not show neither the full complexity of the situation of the country nor its financial situation. The situation is really grave, as (Orlowski W. M., 2014):

- tax revenues do not get to the state coffers, most funds are transferred to foreign accounts owned by a small group of oligarchs,

- the country owes money mainly to investors from abroad, and both the government and the private sector are indebted,

- $\quad$ in the case of Ukraine, the bulk of the debt is short-term and should be repaid in 2015 ,

- Ukraine's foreign currency reserves decreased by half to a dangerously low level of \$ 15 billion,

- Fitch agency downgraded Ukraine's solvency rating from "B minus" level to "CCC" level, which in practice means that the country is soon to be bankrupt.

- Standard and Poor's rating agency downgraded Ukraine's rank from "B minus" to "CCC plus" level, explaining their decision by political instability in the country and no likely improvement,

- given its insolvency, Ukraine has nowhere to go to borrow money in order to survive the coming months. The amounts provided by the West do not even cover a fraction of its needs.

Some experts are predicting that Ukraine is soon going to break up into two completely separate states (Dugin A., 2014, p.4). They argue it will be brought about by the clear linguistic and ethnic division as well as by poor efficiency and fragility of the state apparatus. They also emphasise the historical and civilisational distinction of the eastern part of the country in relation to its western part

\section{Impact of the Conflict on Russia}


Russia cannot lose the conflict in Ukraine. Its defeat would mean a fiasco of the policy hitherto implemented by President Putin. Such course of action could shake the foundations of power throughout the entire Federation and oust the current Kremlin residents. Awkward questions would arise about the validity of the political line adopted and about the costs of the sacrifices made by the society. It would also break the bond uniting the whole nation in a huge effort. The slogan "Without Ukraine, Russia will never be a superpower" produced a significant increase in public support for Vladimir Putin. Seizing Crimea and military intervention in Ukraine, in turn, resulted in an approval for his actions at the level of $90 \%$. The sense of participation in the reconstruction of the former power recognised in the entire world, allows the public to tolerate the lack of democratic freedoms and humiliations experienced (Wildstein B., 2014, p. 18). For centuries, territorial expansion has been an important element for the functioning of the country. First it was the main drive of the state of the tsars, then of the Soviet Union, and now appears as a powerful flywheel for contemporary Russia (Mitin S., 2014, pp. 64 - 67). In response to the actions of Moscow, the United States and the European Union had political and economic sanctions introduced. The more Russia became involved in the conflict in Ukraine, the more severe those sanctions were. They gradually intensified passing through subsequent phases and consisted of (Szymańska - Borginon K., 2014):

- interruption of talks held between the EU and Russia regarding the alleviation of the visa regime,

- suspension of negotiations between the EU and Russia concerning a new cooperation agreement,

- prohibition entry to more than a hundred people from Russia and Ukraine to the USA and the EU and freezing their bank assets,

- embargo imposed by the USA and the EU on trade in arms and military equipment with Russia,

- exclusion of Russia from the group of the most influential countries in the world colloquially known as G8

- prohibition on seeking funds in the European capital markets for companies operating in the defence industry and for national oil companies from Russia,

- suspension of military cooperation between the USA and Russia,

- prohibition for selected Russian banks to issue securities in Japan and intensified inspections aimed at preventing exports from that country to Russia of weapons and equipment needed in the armed forces,

- preventing Russian banks from acquiring funds in the American and European markets,

- prohibiting Russia to sell technology enabling extraction of crude oil and exploration of offshore deposits of raw materials,

- restrictions by the United States and Canada regarding prohibition of exports to Russia of dual-use (civil and military) goods.

- debate on the possibility of taking away from Russia the organisation of the World Cup Football Championship in 2018.

In response to sanctions imposed by the Western countries, on 7 August 2014, Russia introduced a ban on imports of fruit, vegetables, meat, poultry, fish, milk and dairy products from the USA, European Union, Australia, Canada and Norway. It is worth mentioning here that in 2013, the Russian Federation purchased abroad food products worth 43 billion dollars. Moscow also announced further visa restrictions prohibiting certain people's entry to the RF. They were to apply mainly to the citizens of the United States and of the EU in the same number in which it affected citizens of Russia who were refused entry to the West. Those included 12 American soldiers who, according to Moscow, are responsible for torturing prisoners at Guantanamo, Cuba and Abu Ghraib prison in Iraq. Restrictions imposed by Russia soon translated to changes in food prices. According to estimates, in September 2014, in some regions of the country remote from the capital, the citizens had to pay between $10 \%$ and $60 \%$ more than a couple of months before for meat, fruit and vegetables (Malczyk J., 2014). According to prognoses, in the near future Russia will see a further increase in prices, the decline in GDP, increasing unemployment and a substantial economic slowdown. In this context, the GDP growth of $2-2.5 \%$ assumed for 2014 is rather illusory, especially when considered that in 2013 the real GDP growth amounted to only $1.4 \%$ (Szczęsny J., 2014). However, it is difficult to imagine the Russian economy collapsing both in a short and in a long term. Russia owes its significant geopolitical position to revenues from the export of natural gas and crude oil. The share of revenue from the sale of the above natural resources in the total value of Russian exports has been remaining for the past few years at the level of over $50 \%$ and it clearly shows an upward trend. This means that all the rest of the economy is becoming less important. Therefore, as long as Russia finds buyers for its energy resources, it may not be concerned about the stability of its own economy and the supply of the much-needed foreign currency. At the moment, the majority of state expenditure goes towards two sectors, namely social and military. Social expenditure is to guarantee support for the current government in the Kremlin and social peace. The budget for "national defence", according to previous plans, was increased in 2014 to almost 2.5 trillion roubles (about 70 billion dollars) from 2.1 trillion 
roubles in 2013. In nominal terms, Russian expenditure on armaments increased by $92.3 \%$ compared to 2010. Russian military budget currently amounts to $3.4 \%$ of gross domestic product and to as much as $20 \%$ of total state expenditure. Further $16.5 \%$ of the Russian budget is absorbed by other defence and law enforcement institutions. In 2015, military and army spending are expected to absorb 4\% of GDP and reach a record high of 82 billion dollars. Russian authorities are currently implementing an ambitious program for increasing armaments expenditure by more than one-third by the year 2016 (Kolany K., 2014). The goal of the efforts made in the area of the military is to modernise the maintained army over a few years period, to increase its number and operational capacity and thus make Russia again a major player in the international arena.

\section{Impact of the Conflict on Europe}

Russia is the second largest (following United States) sales market for goods and services for the EU. In 2013, EU exports to the Russian Federation amounted to $€ 11.372$ billion. According to the statement of the European Commission, the Russian embargo on agricultural and food products is to cost the whole group integration approximately E5 billion 252 million. It is currently difficult to verify this data. However, some experts claim that the potential damage to the Old World agriculture caused by the Russian retaliatory sanctions may amount to as much as over $\mathrm{C} 7$ billion. According to preliminary estimates, of all the EU-28, the largest financial losses are going to affect (Cukiernik T., 2014, p. 16):

- $\quad$ Lithuania - 6927 million

- Poland - E841 million

- Germany - E595 million

- The Netherlands - $E 528$ million

- Italy - $\mathrm{C412}$ million
- Denmark - E377 million

- Spain - E338 million

- Finland- -6283 million

- Belgium - E281 million, - France- E244 million.

However, the losses will be smaller than expected, as Russia, when imposing restrictions on the Union, limited the suspension of imports to selected products only. In the economic sphere, the United Europe will successfully extricate itself from its current difficult situation in the search for new sales markets, while the political situation of the Old World has become really complicated. There has been a split in the very bosom of the European Union. Some of its members strongly advocate further sanctions against Russia. These are the following: Czech Republic, Estonia, Denmark, the Netherlands, Lithuania, Latvia, Poland, Sweden and the United Kingdom. The harm of further tightening of sanctions is emphasised by (Szymanowski, M., 2014, pp. 58 - 59): Austria, Bulgaria, Cyprus, Greece, Spain, Portugal, Slovakia, Hungary, Italy, and through the mass media and unofficial non-governmental sources also France and Germany. Other countries belonging to the European Union openly express their doubts as to the validity of restrictions and they have not taken a clear common stance in relation to the existing problem. Thus the crisis in Ukraine has effectively led to the differentiation and polarisation of views and to a clear, yet broad division in the sphere of the common foreign policy of the Union.

However, what is the most dangerous for post-war Europe, is the departure from the status quo, or the inviolability of the borders of our continent. The annexation of Crimea and the secession of Eastern Ukraine were a dangerous precedent that could cause unimaginable, or even tragic changes in the coming future. Further prolongation of the conflict or its escalation are capable of leading to uncontrolled imbalance in the part of the world we inhabit. It might result in a change of the hitherto existing boundaries, creation of entirely new state organisms, resumption of old conflicts in traditionally "conflictual regions", establishment of new influence zones and consent to use force in international disputes.

\section{Implications of the Conflict in Ukraine - Broader Dimension}

The ongoing conflict in Ukraine has a limited range, but it is only in geographical terms. Its political and economic influence extends over a much wider area, including Russia and the entire Europe, as well as Japan, USA and Canada. At the beginning of autumn 2014, its intensity has much weakened, giving those who observed it a false impression of 
extinction, and those affected by it a hope for a just peace. It seems that the situation in Donetsk and Lugansk entered the phase of "Palestinisation". This means that military actions will sometimes lose their intensity only to explode twice as violently when the interests of one of the participants require so. The conflict only apparently relates to Ukrainian forces and Separatist troops. Indirectly, it also affects numerous state and economic entities that have favoured one of the feuding parties. The surprising aspect of the Ukrainian dispute is its long duration and regional character. What is really puzzling, is the fact that the military conflict has not yet spread further to the West and that it has not involved larger Russian forces. This can be explained by the activity in the political sphere of selected European countries in cooperation with the United States. The purpose of this activity would be to stop and discourage Russia to aggressive actions, both now and in the future. Another explanation would be an intended action by Moscow, planned to bring in the near future a change in the order of things already existing in the world. Of course, Russia is currently too weak to do this alone. In most areas of its international activity it needs strong political and economic support of allies with common aspirations. This idea is implemented by the Kremlin authorities in two ways. First, there is the ever-recurring idea of creating a Eurasian Union, which makes one think of the attempt to reintegrate the Soviet Union. Secondly, there is the ongoing creation of the association of the "BRICS", countries whose purpose is to oppose the dominance of Western countries on our planet. The five BRICS members are Brazil, China, India, Russia and South Africa. In total, they occupy $26 \%$ of the total land area of the Earth. They are inhabited by approximately 3 billion people, which represents over $40 \%$ of the population of our planet. Their economies account for about one-fifth of the GDP of the entire world (Strzępka K., 2014). They are the most powerful countries in their regions. They have common characteristics, common interests, and some analysts believe that they have found a common enemy, namely the United States (Skowronek T., 2014). It seems that within the BRICS organisation, Russia is closest to China. The relationship between these two powers is much better than with the other members of the association of the five countries. It is thanks to China that Russia can afford to do what it's currently doing in Europe. This is due to the contract for the supply of gas to the Middle Kingdom signed in May 2014. Media informed that a document signed in Shanghai in the presence of the presidents of both countries concerns the supply of 38 billion cubic meters of gas per year for 30 years and amounts to over 400 billion dollars (Kublik A., 2014). The People's Republic of China has also benefited from the agreement. Ensuring uninterrupted gas supply from a friendly neighbour allows the authorities in Beijing to focus on the dynamic development of the country, to organise the internal affairs and to gain effective independence from whatever market situation. It should be noted here that the signing of the gas contract in Shanghai was preceded by heated negotiations lasting no less than 10 years. Talks so long can be ascribed one reason. It can be expected that the concluded agreement also has a yet undisclosed part in which important matters have been determined concerning international problems and in which the common strategy on global politics has also been specified. Both countries have quite an experience in concluding secret agreements. To justify this claim it is enough to give examples of agreements that became publicly known despite their confidentiality clauses:

- a secret agreement between Uzbekistan and China on gas supplies dated October 2011,

- $\quad$ secret agreement on cooperation between Microsoft and the Government of China dated December 2011,

- German-Soviet Molotov-Ribbentrop Pact. An agreement concluded in August 1939 on the delimitation of zones of mutual interests in Eastern Europe,

- $\quad$ secret agreement Merkel-Putin dated July 2014 on the conditions of ending the crisis in Ukraine.

Many facts support the hypothesis of concluding an additional secret agreement when signing the contract in Shanghai. For example, recently there has been observed a disturbing Russia's military activity in Europe and near the United States territory. Moreover, there have been intensified movements and open military actions of People's China in South-East Asia and in the Pacific Islands area. However, contrary to many fears, these actions should not be seen as a prelude to a large armed conflict or seeking confrontation on a global scale. Rather, they are trying to probe the determination of the USA and Western Europe within Atlantic Alliance to defend their own positions and their status of ownership. Another interesting issue is cessation of any mutual territorial disputes between Russia and China. Neither are there any conflicts on the long common border between the two countries, although minor armed incidents often occurred there in the past. Interestingly, Russia has consistently refrained from criticism of China in the international arena, and China likewise does not condemn the actions of Russia in Ukraine. These data may indicate 
that mutual zones of influence have been appointed between the two superpowers and that a united policy concerning key issues of the upcoming future has been adopted.

\section{Conclusion}

Crisis in Ukraine and the outbreak of an armed conflict in its territory proved the fragility of conventions relating to the borders and to the European order. Agreements on these important settlements were concluded after World War II with full legitimacy and mutual respect. Now, wwe are witnessing the development of a new world order, while the existing order is just becoming history. The current world saw the reactivation of old players such as Russia, Germany and China. And it is those countries that will have their say in the near future rather than others. Such players as the United States, Lithuania, Latvia, Estonia, Finland, Slovakia, Poland and Ukraine have a very difficult time ahead of them. New alliances and agreements reduce their international position and marginalise their political role. The economic situation created as a result of the Ukrainian conflict in the east of the Old Continent weakens to a greater extent smaller and medium-sized countries than the large and economically strong ones. Protracted crisis negatively affects the political and economic sphere not only on a European, but also global scale. It hinders trade, increases the military spending pool, distorts international cooperation in many areas, including in science and culture, interferes with the free movement of capital and people, limits economic growth, destroys the industrial infrastructure, raises prices and brings about a sense of uncertainty and disappointment. In 1994, Ukraine resigned from the possession of nuclear weapons. In return for this gesture it received a joint guarantee from the USA, Great Britain and Russia on the inviolability of its borders. It was an international agreement. The great powers failing to comply with their previous promises have put into question the integrity and the good intentions of their governments. It also started social unrest and insecurity. At the moment it seems that the future of Ukraine has already been decided, and that decisions concerning its fate have been made behind closed doors without the participation of its representatives. Striving to ensure their own further economic development, both Russia and the European Union led by Germany will not hesitate to take radical steps and will seek to divide Ukraine into two subordinate zones of influence. China, with their secured rich resource base in Siberia and tranquillity on the northern border will gain momentum at the expense of the declining United States. First, their predomination will be seen in the Far East, then in most parts of the Pacific, to achieve global dominance by the end of the second decade of the twenty-first century. The accuracy of the prognoses outlined in this paper is to be put to the test by the events which we will witness in the coming months and years.

\section{Bibliography}

1. Bohun T., (2014), Chruszczow i Krym, Mówią Wieki, No. 4 (651), 04 / 2014, Warsaw.

2. Cukiernik T., Komu szkodzą sankcje?, Najwyższy Czas!, No. 34 - 35 (1266 - 1267), Year XXV, 23 - 30 August 2014, Warsaw.

3. Dugin A., (2014), Rozpad Ukrainy jest nieuchronny, Myśl Polska, No. 7 - 8, 16 - 23 II 2014 , Warsaw.

4. Góralski M. W., (2007), Koncepcja ustrojowa i instytucjonalna II filara Unii Europejskiej. In Góralski M.W., Unia Europejska. Gospodarka - Polityka - Współpraca. Vol. II., WoltersKluwer Polska Sp. z o.o., Warsaw.

5. Kolany K., (2014), Rosja zwiększa wydatki na wojsko, Bankier.pl, from http://www.bankier.pl/wiadomosc/Rosja-zwieksza-wydatki-na-wojsko-3099681.html

6. Kublik A., (2014), Chiny i Rosja gazem połączone. Jakie są szczegóły wielkiego kontraktu? MAKGazeta Wyborcza.pl / Świat, z dn. 22.05.2014. from http://wyborcza.pl/1,75477,Chiny_i_Rosja_gazem_polaczone_Jakie_sa_szczegoly.html

7. Malczyk J., Rosną ceny hurtowe i detaliczne żywności w Rosji, PAP, from http://finanse.wp.pl/kat,138596,title,Rosna-ceny-hurtowe-i-detaliczne-zywnosci-w Rosji,wid,16824509, wiadomosc.html?ticaid=11386e 
8. Mitin S., (2014), Jak zdobywano Syberię, Focus Historia ekstra, No. 5/2014, October November, Warsaw.

9. Orlowski W. M., (2014), Czy dług Ukrainy jest wysoki ?,Rzeczpospolita, from http://www.ekonomia.rp.pl/artykul/1090466.html

10. Skowronek T., (2014), BRICS - 5 potęg, Portal Geopolityka.org, Stowarzyszenia Europejskie Centrum Analiz Geopolitycznych, 29.10.2011, from http://www.geopolityka.org/analizy/1133brics-5-poteg

11. Strzępka K., (2014), BRICS - za dużo różnic na sukces ?, PAP, 20.07.2014, from http://www.bankier.pl/wiadomosc/BRICS-za-duzo-roznic-na-sukces-3166069.html

12. Swieciński P., (2014), Ukraina - wnioski, w Sieci, No. 38 (94), 15 - 21.09.2014, Warsaw.

13. Szczęsny J., (2014), Rosja - perspektywy rozwoju gospodarczego w 2014 roku, Instytut INTL, from http://www.instytutintl.pl/pl/aktualnosci/item/493-rosja-perspektywy-rozwojugospodarczego-w-2014-roku

14. Szymańska - Borginon K., ( 2014 ), Nowe sankcje wobec Rosji przyjęte. RMF 24, from http://www.rmf24.pl/raport-ukraina/fakty/news-nowe-sankcje-wobec-rosjiprzyjete,nId,1497156

15. Szymanowski M., (2014 ), Ostrożni wobec Rosji, Do Rzeczy, No. 37/085, 8 - 14 September 2014, Warsaw.

16. Tichomirow W., ( 2005 ), Próba przystąpienia ZSRR do NATO, Ogoniok 21.03.2005, from http://forum.gazeta.pl/forum.html

17. Wildstein B., ( 2014 ), Nasza wojna na Ukrainie, Do Rzeczy, No. 36/084, 1-7 September2014, Warsaw. 